Advocates may persuade us that the answers to all these questions are "yes" and that "clean nicotine" is the best course to pursue. Equally there is an onus on those who do not like the idea to come up with something better ... for to do as little as we currently do for the world's 1.1 billion smokers is surely not conscionable.

MICHELLE SCOLLO

VicHealth Tobacco Control Centre,

100 Drummond Street,

Carlton, Vic 3053, Australia

mscollo@bigpond.net.au
1 Silagy CPB, Gduo G, Scollo M, Borland R. Modelling the effects of adopting a harm minimisation approach to smoking cessation. First International Meeting, Society forResearch into Nicotine and Tobacco, 22-23 August 1998. Copenhagen, Denmark.

2 Kawachi ICG, Stampfer MJ, Willett WC, et al. Smoking cessation and time course of decreased risks of coronary heart disease in middle aged-women. Arch Intern Med heart disease in

3 Peto R. The influence of dose and duration of smoking on lung cancer rates. In: Zaridze PR, ed. Tobacco: a major international health hazard. Lyon: International Agency for Research on Cancer, 1986.

4 Bates C, McNeill A, Jarvis M, Gray N. The future of tobacco product regulation and labelling in Europe: implications for the forthcoming European Union directive. Tobacco Control 1999:8:225-36.

\title{
DEBATE
}

\section{Compete with the tobacco industry}

The future outlined by Clive Bates is one in which public health joins with the pharmaceutical industry to design nicotine delivery devices that deliver the same addictive hit as cigarettes with lower toxicity. Rather than going into business with the pharmaceutical industry to compete with the tobacco industry to deliver nicotine, we should be competing with big tobacco to increase the market share of non-smokers.

While there is nothing wrong with continued legal and regulatory pressure to force the tobacco industry to market less dangerous products, the experience in California shows that it is possible to reduce tobacco consumption rapidly with an aggressive campaign that denormalises the tobacco industry, and promotes the dangers of passive smoking so as to undercut the social acceptability of smoking. The key innovation in the California programme was to speak to the non-smokers as much or more as the smokers. In the early years, before the programme was cut and toned down, we were on a path towards a $60 \%$ reduction in tobacco use in just 10 years. ${ }^{1-4}$

The fact that the Europeans have chosen to concentrate on trying to regulate the tobacco industry and run traditional quit smoking programmes rather than enlist the non-smokers in the battle for clean indoor air may explain why progress there has been so slow, despite stronger public support for non-smokers' rights in Europe than in the USA 10 years ago. ${ }^{56}$

An aggressive, broad based tobacco control programme that includes everyone-including the non-smokers - could go a long way towards eliminating the problem in 10 years. All that we need is the political will to make it happen.

STANTON A GLANTZ

Institute for Health Policy Studies,

Cardiovascular Research Institute,

University of California,

San Francisco, CA 94143 USA

glantz@medicine.ucsf.edu

1 Glantz SA. Changes in cigarette consumption, prices, and tobacco industry revenues associated with California's
proposition 99 . Tobacco Control 1993;2:311-14.

2 Pierce JP, Gilpin EA, Emery SL, White M, Rosbrook B, Berry C. Has the California tobacco control program reduced smoking. FAMA 1998;280:893-9.

3 Pierce JP, Gilpin EA, Emery SL, et al. Tobacco control in California: who's winning the war. San Diego: University of California at San Diego, 1998.

4 Glantz SA, Balbach EB. Tobacco war: inside the California battles. Berkeley, California: University of California Press, 2000.

5 Glantz SA, Charlesworth A. Tourism and hotel revenues before and after passage of smoke free restaurant ordinances. ҰAMA 1999;281:1911-18.

6 Philip Morris Incorporated. Tobacco issues 1989: how today's smokers and nonsmokers in Europe feel about smoking issues. smokers and nonsmokers in Europe feel about smoking issues. 1999. 